\title{
CORPORATE SOCIAL RESPONSIBILITY AND CUSTOMER LOYALTY: EXPLORING THE ROLE OF IDENTIFICATION, SATISFACTION AND TYPE OF COMPANY
}

\begin{abstract}
Purpose - The authors of this paper propose a cognitive-affective-conative sequential model to study how three dimensions of corporate social responsibility (CSR) image (society, customers and employees) impact customer affective (identification and satisfaction) and behavioural (recommendation and repurchase) responses in the banking industry. The authors also test how the type of company (savings banks vs. commercial banks) moderates customer responses to these three dimensions of CSR image.

Design/methodology/approach - A multi group structural equation model (SEM) is tested using information collected from 648 savings banks customers and 476 commercial banks customers in Spain.

Findings - The findings demonstrate that the perceptions of customer-centric CSR initiatives positively and consistently impact customer identification with the banking institution, satisfaction, recommendation and repurchase behaviours in the savings banks and commercial banks samples. The dimensions of CSR image that concern the activities oriented to society and employees only positively impact customer responses in the savings banks sample.

Practical implications - The findings of this study can assist scholars in creating more informative CSRbased loyalty models that take into consideration new variables (satisfaction and type of company) and better approaches to the conceptualization of CSR image (e.g., the formative approach). The findings can also assist savings banks and commercial banks in better designing their CSR and communication initiatives to benefit from customer affective and conative responses.
\end{abstract}

Originality/value - The contributions of the paper are threefold: (1) the authors include satisfaction as a new variable in the study of the CSR-based loyalty model; (2) CSR image is conceptualized as a formative construct and this provides new justifications for the mixed results reported by previous scholars who have analysed the effects of CSR image on customer loyalty and (3) the authors explore the moderating role of the type of company on the CSR-based loyalty model proposed in the paper.

KEYWORDS: CSR image; customers; identification; satisfaction; loyalty; banking industry 


\section{INTRODUCTION}

Loyalty behaviour is one of the most representative ways in which customers express their satisfaction with corporate performance and it is closely linked to the profitability of companies (García de los Salmones et al., 2009). Nonetheless, loyalty is a complex concept, and the models that scholars apply to describe its formation continue finishing off with the plus of new variables with explicative power. Along this line, scholars have started to consider the inclusion of corporate social responsibility (CSR) image in loyalty behaviour models. However, the results of these studies generate controversy because empirical evidence keeps showing contradictory results. While some scholars perceive positive effects of CSR image on customer loyalty (Pérez et al., 2013), this influence is rejected in other studies (Carrigan and Attalla, 2001). Thus, new research is needed in this field to clarify the role of CSR image in the formation of customer loyalty behaviours.

Based on these ideas, the purpose of the authors of this paper is to test a conceptual model of CSR image and customer loyalty that overcomes the flaws prevalent in prior models and reflects the latest ideas discussed by scholars concerning both realities. For this purpose, the authors take the paper of Pérez and Rodríguez del Bosque (2013) as the reference for designing their study. This paper is one of the latest approaches to the study of CSR image and customer loyalty that have been published in a top ranked journal (Journal of Business Ethics). The purpose of Pérez and Rodríguez del Bosque (2013) is to test the reliability and validity of a new stakeholder-based CSR image scale by including it in a causal model to understand the way CSR image influences customer loyalty. The model includes four concepts: CSR image, customer-company (C-C) identification, repurchase behaviour and willingness to recommend. Their findings demonstrate the adequacy of a multidimensional 
scale (19 items gathered in 4 dimensions) to understand CSR image in the banking industry. Their study also validates the causal model and demonstrates that CSR image directly and positively determines identification, repurchase and recommendation behaviours.

Nonetheless, the authors of the present study have identified three weaknesses of the paper of Pérez and Rodríguez del Bosque (2013) that justify this new research.

First, recent studies have criticized that customer satisfaction with companies has not been studied in depth in research analysing the role of corporate associations (including CSR) in customer loyalty (Pérez et al., 2013). Pérez and Rodríguez del Bosque (2013) are clear examples of researchers who have failed to include this construct in their conceptual framework. Nonetheless, satisfaction has been traditionally considered as the most relevant antecedent of customer loyalty behaviours (Oliver, 1997) and thus its omission in models based on CSR seems unjustified. In the present paper, the authors consider that satisfaction is both an affective and cognitive customer response to CSR image and that, along with C-C identification, it finally determines the attitudinal and behavioural loyalty of customers towards their services providers.

Secondly, in the present paper CSR image is conceptualized as a formative construct (Burke et al., 2003), which provides further information than the reflective conceptualization that has been used by Pérez and Rodríguez del Bosque (2013) and most previous scholars (Brown and Dacin, 1997; Pérez et al., 2013). Pérez and Rodríguez del Bosque (2013) expected the four dimensions of CSR image (customers, shareholders and supervising boards, employees and society) to be correlated, possess internal consistency and have the same impact on customer loyalty. Thus, all the dimensions were reflected in a second-order construct. Nonetheless, the authors of the present paper conceptualize CSR image as a 
formative construct because they consider that each dimension has the potential to be mutually exclusive in such a way that the effects of each dimension on customer loyalty can be different (Burke et al., 2003). This idea is supported by previous scholars who have demonstrated that some dimensions of CSR image might inversely correlate with others (Singh et al., 2008). Thus, the independent effect of the dimensions of CSR image on customer loyalty must be tested, because it could help scholars and practitioners to better understand the role of CSR image in customer markets.

Thirdly, the authors of this paper include the type of company as a moderator construct in the conceptual model. Pérez and Rodríguez del Bosque (2013) test their model in a sample of 1,124 customers of banks and savings banks indistinctively. Thus, they do not account for differences in the way customers perceive CSR, even when these two types of banking institutions have different CSR tradition and focus their attention on diverse stakeholders (Pérez and Rodríguez del Bosque, 2012). For example, savings banks are non-profit companies with a strong community and social orientation, whereas commercial banks are focused on profit maximization and shareholder value (Pérez and Rodríguez del Bosque, 2012). Based on these differences, in this paper the authors propose that customers of savings banks and commercial banks process information differently and that the consequences of the dimensions of CSR image in their loyalty are also diverse.

Based on all these ideas, the contributions of the present paper to literature are threefold. First, the authors conceptualize CSR image from a formative approach and include three dimensions of CSR image (CSR towards society, customers and employees) on a causal model to understand customer affective (C-C identification and satisfaction) and conative (recommendation and repurchase) responses in the banking industry. Secondly, the authors 
complete the loyalty behaviour model by including customer satisfaction. Finally, the authors analyse the role that the type of company (savings banks vs. commercial banks) plays in the loyalty behaviour model.

\section{CONCEPTUAL FRAMEWORK}

Along with the work of Pérez and Rodríguez del Bosque (2013), the conceptual framework of this paper is built on the principles of the hierarchy of effects model. This approach considers that the stages of customer behaviour are divided into (1) the cognitive dimension, which refers to customer thoughts and beliefs (CSR image), (2) the affective dimension, referring to the realm of emotions (C-C identification and satisfaction), and (3) the conative dimension, referring to customer behavioural intentions and actions (recommendation and repurchase behaviour).

As one of the major contributions of the paper, the authors independently analyse the influence of three dimensions of CSR image (society, customers and employees) on customer behaviour. The three dimensions chosen for this research are those that scholars have demonstrated to be more closely related to customers (Marquina and Vasquez, 2013). In this regard, scholars have defined social (society), product (customers) and human (employees) responsibilities as the three core subjects expressing responsible behaviour as perceived by customers (Marquina and Vasquez, 2013). The authors deliberately exclude the shareholder dimension from the analysis because its influence on customer behaviour has been largely

questioned by scholars (Aupperle et al., 1985; García de los Salmones et al., 2005). Aupperle et al. (1985) conclude that CSR can be measured in terms of the importance of three noneconomic components (ethics, law and philanthropy). They observe that the economic 
dimension (reflected in the shareholder dimension proposed by Pérez and Rodríguez del Bosque, 2013) is inversely correlated with the other three. When customers' perceptions about companies' responsible behaviour are examined, this result is much clearer (Maignan and Ferrell, 2001). García de los Salmones et al. (2005) empirically demonstrate that the economic behaviour of companies is perceived as an independent factor of corporate behaviour by customers.

Figure 1 is a summary of the proposed conceptual model tested in this research, which is explained in detail next.

\section{Insert Figure 1 about here}

CSR image has a direct and positive effect on C-C identification (García de los Salmones et al., 2009; Marín et al., 2009). CSR image acts as a transceiver of a differentiated system of values and it supports the appeal of corporate identities (Sen et al., 2006). Customers will only identify with those companies whose identity looks attractive, because they perceive them close to their own identities and they share common values and principles. Accordingly, CSR image strengthens customers' feelings of identification towards companies and induce them to develop a sense of connection with them (García de los Salmones et al., 2009; Matute et al., 2011).

This idea may be accepted for the three dimensions of CSR image proposed in this paper. First, CSR initiatives towards society encompass philanthropic actions such as sponsorship, infrastructure investments or donations to community projects, among others. All these CSR initiatives lead to the creation of added value not only to the society but to the company as 
well, because they reflect a brand personality that is in line with altruistic values that could give place to connection and identification states with their customers (Sen et al., 2006). Secondly, customers are known to specially notice the more tangible aspects of companies that might influence their buying decisions directly, such as quality, innovation, compliance to standards, guarantees and other information provided about the product (Maignan and Ferrell, 2001). Thus, customers usually respond more positively to customer-centric initiatives than to other types of CSR image. Finally, Marquina and Vasquez (2013) demonstrate that CSR image concerning employee affairs also positively affect customer behaviour.

H1: Customer perceptions about the CSR oriented to society (CSR society) directly and positively influence $\mathrm{C}-\mathrm{C}$ identification.

H2: Customer perceptions about the CSR oriented to customers (CSR customers) directly and positively influence $\mathrm{C}-\mathrm{C}$ identification.

H3: Customer perceptions about the CSR oriented to employees (CSR employees) directly and positively influence $\mathrm{C}-\mathrm{C}$ identification.

Along this line, the authors propose that some dimensions of CSR image can also influence satisfaction directly and positively. The equity theory argues that customers can be potentially other types of stakeholders who care not only for the economic value of consumption but also for the overall standing of a company, including the fairness of its CSR initiatives towards different stakeholder groups (Oliver, 1997). When this is the case, customers are likely to be more satisfied if the company is socially responsible towards different stakeholders such as employees or customers themselves. 
In this regard, the scarce number of scholars who have analysed the impact of some dimensions of CSR image on customer behaviour have demonstrated that both CSR towards customers and employees impact customer satisfaction positively (García de los Salmones et al., 2009; Marquina and Vasquez, 2013). However, this does not seem to be the case for the dimension of society issues. In this case, it seems that philanthropic initiatives go relatively unnoticed mainly because the influence on customers is usually indirect and these issues are of secondary importance for them (Singh et al., 2008). This lack of awareness may become an inhibitor of consumer sensitivity and explain why they might not be taken into account while appraising a company and the satisfaction with its service performance (Singh et al., 2008). Identifying with a company is significantly different to be satisfied with it. Satisfaction implies a feeling of higher involvement for customers than identification and as so it is not as easily achieved as identification.

H4: Customer perceptions about the CSR oriented to customers (CSR customers) directly and positively influence customer satisfaction.

H5: Customer perceptions about the CSR oriented to employees (CSR employees) directly and positively influence customer satisfaction.

Anyway, scholars consider that a company that is skilled in meeting the customer's needs for self-definition must also be a company the consumer is satisfied with (Pérez et al., 2013). The expectation disconfirmation theory suggests that customers are more likely to be satisfied when corporate performance confirms or exceeds prior expectations ( $\mathrm{He}$ and $\mathrm{Li}, 2011)$. Along this line, C-C identification provides a more favourable context for customers to respond to corporate performance experiences as against to prior expectations. When corporate performance expectations are confirmed or exceeded, customers with stronger C-C 
identification would be more satisfied, since the confirmation of their expectations reassures customers of their psychological attachment with the company, which in turn helps them to preserve their self-esteem ( $\mathrm{He}$ and $\mathrm{Li}, 2011)$. Additionally, when corporate performance expectations are not confirmed, customers with stronger $\mathrm{C}-\mathrm{C}$ identification tend to be less dissatisfied due to their more affective attachment to the company and more resilience to bad information and experiences.

\section{H6: C-C identification directly and positively influences customer satisfaction.}

The last phase of the hierarchy of effects model proposed in this paper is composed of customer loyalty responses (recommendation and repurchase behaviour) to CSR image. Scholars have demonstrated that through the consumption and recommendation of products and services from a company, customers reinforce their identities and as so the higher their identification with a company's values, the higher their loyalty towards it and the wish to establish long-term relationships (García de los Salmones et al., 2009). Scholars aligning with the theory of the extended-self consider that recommendation and purchases become acts of expressing and projecting the self, necessary for personal definition. Thus, once identified with the company, customers use consumption and communication as ways of expressing their own identities, and as so customers are more likely to support companies with which they identify (Marín et al., 2009). In essence, identifying with a company is likely to be associated with a desire to enhance the company's welfare and customer support is oriented towards this goal. In the context of the banking industry, this idea is reported by García de los Salmones et al. (2009), Marín et al. (2009) and Pérez et al. (2013). 
H7: C-C identification directly and positively influences customer recommendation behaviour.

H8: C-C identification directly and positively influences customer repurchase behaviour.

Finally, two extensively accepted research hypotheses are proposed to complete the cognitive-affective-conative model described in this paper. Specifically, a direct and positive link between customer satisfaction and customer (1) recommendation and (2) repurchase behaviours is proposed (García de los Salmones et al., 2009; Matute et al., 2011; Pérez et al., 2013).

H9: Customer satisfaction directly and positively influences customer recommendation behaviour.

H10: Customer satisfaction directly and positively influences customer repurchase behaviour.

The Moderating Effect of the Type of Company: Savings Banks vs. Commercial Banks

The authors further propose that the type of company that customers evaluate moderates the impact of CSR image on customer affective and conative responses. In this regard, two types of banking institutions (savings banks and commercial banks) have traditionally operated in the banking systems of most of the industrialized countries in the world (Salas and Saurina, 2002; Illueca et al., 2009). These two subsectors contain over 95 per cent of the banking assets in these countries (Salas and Saurina, 2002). 
Savings banks and commercial banks have different origins and their organizational structure has influenced their CSR management significantly. On the one hand, savings banks began as mutual (non-profit making) organizations, and in several countries they have a significant state ownership and other kinds of state involvement. Their corporate strategy and scope has traditionally made savings banks more focused on local credit businesses because the ownership is shared among representatives of several stakeholder groups such as local and regional government, the founding entity, depositors and employees (Salas and Saurina, 2002). In addition, their social dividend is also a distinguishing historical characteristic of savings banks. In this regard, the profits of savings banks must be either retained or distributed in cultural and social community programs (Salas and Saurina, 2002; Illueca et al., 2009). On the other hand, commercial banks are for-profit companies under shareholders control (Salas and Saurina, 2002). Their shares are in the hands of families, individual and institutional investors and as so the inclusion of CSR in their strategies is more recent than in savings banks (Illueca et al., 2009). Commercial banks have traditionally been more concerned with providing universal banking services according to reasonable efficiency standards and a strong customer orientation (Pérez and Rodríguez del Bosque, 2012).

According to these corporate characteristics, the authors propose that, while commercial banks customers may respond better to the CSR initiatives oriented to customers than savings banks customers, the latter may respond better to the CSR initiatives that savings banks promote regarding the society and employees, because several representatives of these stakeholders take part in the managerial decisions of this type of banking institutions. Thus, customer perceptions of the three dimensions of CSR image will derive in a different intensity of the affective and conative responses of customers. Along this line, the authors propose the last research hypothesis and sub hypotheses of the paper: 
H11: The type of company moderates the effects of the dimensions of CSR image on customer affective and conative responses:

H11a: Customer perceptions about the CSR oriented to society (CSR society) have a stronger positive effect on $\mathrm{C}$ - $\mathrm{C}$ identification for savings banks customers than commercial banks customers.

H11b: Customer perceptions about the CSR oriented to customers (CSR customers) have a stronger positive effect on $\mathrm{C}$-C identification for commercial banks customers than savings banks customers.

H11c: Customer perceptions about the CSR oriented to customers (CSR customers) have a stronger positive effect on customer satisfaction for commercial banks customers than savings banks customers.

H11d: Customer perceptions about the CSR oriented to employees (CSR employees) have a stronger positive effect on C-C identification for savings banks customers than commercial banks customers.

H11e: Customer perceptions about the CSR oriented to employees (CSR employees) have a stronger positive effect on customer satisfaction for savings banks customers than commercial banks customers.

\section{METHOD}

For the testing of the hypotheses, a quantitative study based on personal surveys on customers of savings banks and commercial banks in Spain was conducted. The surveys were filled up in in-depth interviews that were undertaken along one month in spring 2010. Customers only had to evaluate their main banking company. After the collection and 
processing of information, a total of 1,124 valid surveys remained (response rate=93.7\%). 648 customers evaluated a total of fourteen savings banks while 476 customers evaluated seven commercial banks.

\section{Sample Profile}

A non-probabilistic procedure was used to select respondents to the survey. Respondents were customers of banking services over 18 years of age. With the purpose of guaranteeing a more accurate representation of the data, a multi-stage sampling by quotas was used to select respondents to the survey based on customer gender and age (Pérez et al., 2013). The sample was $51.3 \%$ male and $48.7 \%$ female, which was comparable to the population in the country with 51\% male and 49\% female (Instituto Nacional de Estadística, data up to January 1 , 2011). Regarding age, customers in the sample were $46.5 \%$ under 44 (50.1\% in the national population), $33.2 \%$ between 45 and 64 (29.7\% in the national population) and $20.3 \%$ over 64 (20.2\% in the national population).

\section{Measurement Scales}

Seven-point Likert-type scales were used to measure all the concepts in the theoretical model (Table 1). Firstly, the three dimensions of customer CSR image were evaluated by adapting the stakeholder-based scale proposed by Pérez and Rodríguez del Bosque (2013). A six-item scale evaluated customer perceptions about the CSR oriented to society (SOC1 to SOC6) and two five-item scales evaluated CSR oriented to customers (CUS1 to CUS5) and employees (EMP1 to EMP5). C-C identification was measured by means of a six-item scale (IDE1 to IDE6) based on the paper of Bergami and Bagozzi (2000). A four-item scale (SAT1 
to SAT4) was developed to evaluate satisfaction based on Oliver (1997). Finally, customer recommendation and repurchase behaviours were also measured following the proposal of Oliver (1997). Two-item scales were used to evaluate customer recommendation behaviours (REC1 and REC2) and customer repurchase behaviours (REP1 and REP2).

\section{Insert Table 1 about here}

\section{Evaluation of the Psychometric Properties of the Measurement Scales}

Before proceeding to the test of the conceptual model in each of the savings banks and commercial banks samples, the psychometric properties of the scales were tested to ensure that the model properly fitted the data. For this purpose, the authors implemented first-order confirmatory factor analyses (CFA). The results are presented in Tables 2 and 3.

The results confirmed that the Satorra-Bentler chi-square $(\mathrm{S}-\mathrm{B} \chi 2)$ was significant in the savings banks $(\mathrm{S}-\mathrm{B} \chi 2(380)=652.59, \mathrm{p}<0.01)$ and commercial banks samples $(\mathrm{S}-$ $\mathrm{B} \chi 2(380)=1562.21, \mathrm{p}<0.01)$, which may indicate a poor fit of the model to the collected data. However, this result may be due to the large sample size of both samples (over 200 cases), which has been shown to potentially affect the $S-B \chi 2$ test. Consequently, this indicator was complemented with an analysis of the Comparative Fit Indexes -NFI, NNFI, CFI and IFI-. In all cases, these measures exceeded the minimum recommended value of 0.90 , thus confirming the goodness of fit of the proposed model in the savings banks (NFI=0.94; $\mathrm{NNFI}=0.97 ; \mathrm{CFI}=0.97 ; \mathrm{IFI}=0.97)$ and commercial banks samples $(\mathrm{NFI}=0.93 ; \mathrm{NNFI}=0.97$; $\mathrm{CFI}=0.98$; IFI=0.98). Also, the RMSEA index was below the minimum recommended value of 0.08 (RMSEA=0.03 in both samples). The reliability of the measurement scales was 
evaluated by means of the Cronbach's alpha $(\alpha)$ and the average variance extracted index (AVE). In all the cases, these indicators were over the recommended values of 0.7 and 0.5 respectively. The convergent validity of the scales was also contrasted, since all the items were significant to a confidence level of $95 \%$ and their standardized lambda coefficients $(\lambda)$ were higher than 0.5 (Table 2). For the purpose of testing the discriminant validity, the confidence intervals for the correlation between pairs of latent factors were estimated and compared with the unit. It was observed that in none of the cases the proposed intervals contained the value 1 (Table 3 ).

\section{Insert Table 2 about here}

\section{Insert Table 3 about here}

\section{FINDINGS}

Once the validity of the measurement scales was successfully tested, the causal relationships in Figure 1 were estimated in the savings banks and commercial banks samples. The results of both studies were compared using multi group structural equation modeling (SEM) in order to determine how differently the dimensions of CSR image influenced customer affective and conative responses in each sample.

\section{Test of the Conceptual Model among Savings Banks Customers}

The results for savings banks customers are shown in Figure 2. Firstly, C-C identification was significantly and positively influenced by customer perceptions of the CSR oriented to 
the society $(\beta=0.24, \mathrm{p}<0.05)$ and customers $(\beta=0.38, \mathrm{p}<0.05)$ but not by customer perceptions of the CSR oriented to employees $(\beta=0.04, \mathrm{p}>0.05)$. Thus, the hypothesis $\mathrm{H} 1$ and $\mathrm{H} 2$ are supported while the hypotheses H4 is not. Customer perceptions about the CSR oriented to customers also significantly and positively impacted customer satisfaction $(\beta=0.28, \mathrm{p}<0.05)$, as well as the perceptions of the CSR oriented to employees $(\beta=0.08, p>0.05)$. Based on these results, the hypotheses $\mathrm{H} 3$ and $\mathrm{H} 5$ are supported. C-C identification also significantly and positively influenced satisfaction $(\beta=0.56, \mathrm{p}<0.05)$ and customer recommendation behaviour $(\beta=0.28, \mathrm{p}<0.05)$. However, it did not influence customer repurchase behaviour significantly $(\beta=0.05, \mathrm{p}>0.05)$. Thus, the hypotheses $\mathrm{H} 6$ and $\mathrm{H} 7$ are supported while the hypothesis $\mathrm{H} 8$ is not. Finally, satisfaction significantly and positively affected customer recommendation $(\beta=0.59, \mathrm{p}<0.05)$ and repurchase behaviours $(\beta=0.80, \mathrm{p}<0.05)$. Based on these results, the hypotheses H9 and H10 are supported.

\section{Insert Figure 2 about here}

\section{Test of the Conceptual Model among Commercial Banks Customers}

The results of the analysis implemented with the data of the commercial banks sample are shown in Figure 3. Firstly, C-C identification was significantly and positively influenced by customer perceptions of the CSR oriented to customers $(\beta=0.31, p<0.05)$ but not by customer perceptions of the CSR oriented to the society $(\beta=0.08, p>0.05)$ or employees $(\beta=0.06$, $\mathrm{p}>0.05)$. Thus, the hypothesis $\mathrm{H} 2$ is supported while the hypotheses $\mathrm{H} 1$ and $\mathrm{H} 3$ are not. Customer perceptions about the CSR oriented to customers also significantly and positively impacted customer satisfaction $(\beta=0.25, \mathrm{p}<0.05)$, but again the perceptions of the CSR oriented to employees did not significantly affect this affective variable $(\beta=0.06, p>0.05)$. 
Based on these results, the hypothesis H4 is supported while H5 is not. C-C identification also significantly and positively influenced satisfaction $(\beta=0.63, \mathrm{p}<0.05)$, customer recommendation behaviour $(\beta=0.27, \mathrm{p}<0.05)$ and repurchase behaviour $(\beta=0.17, \mathrm{p}<0.05)$. Thus, the hypotheses H6 to H8 are supported. Finally, satisfaction significantly and positively affected customer recommendation $(\beta=0.59, \mathrm{p}<0.05)$ and repurchase behaviours $(\beta=0.82$, $\mathrm{p}<0.05)$. Based on these results, the hypotheses $\mathrm{H} 9$ and $\mathrm{H} 10$ are supported.

\section{Insert Figure 3 about here}

\section{Multi Group Comparison}

With the aim of statistically examining the differences between both samples, a comparison of the intensity of each of the relationships for savings banks and commercial banks customers was carried out by applying a multi group SEM analysis in EQS 6.1. The suitability of the analysis was tested with the Lagrange Multiplier (LM) test. To confirm that the type of company was a moderator of the relationships under scrutiny, it was necessary that the $\chi 2$ differences were significant because this meant that differences existed in the intensity of the relationships between the samples. The results of this analysis are shown in Table 4 and they demonstrate that several relationships in the conceptual model were different among savings banks customers and commercial banks customers. Thus, the type of company is a moderator of the effects of the dimensions of CSR image on customer affective and conative responses in the banking industry (Dif. $\left.\chi^{2}(33)=131.52, p<0.01\right)$. Based on these results, the hypothesis H11 is supported. 
While customer perceptions about the CSR oriented to society positively influenced C-C identification in the savings banks sample $(\beta=0.24, \mathrm{p}<0.05)$, it did not affect the C-C identification of commercial banks customers $(\beta=0.08, p>0.05)\left(\right.$ Dif. $\left.\chi^{2}=2.51, p<0.01\right)$. This result supports the hypothesis H11a. The same trend was perceived in the relationship between customer perceptions about the CSR oriented to employees and customer satisfaction $\left(\beta_{\mathrm{SB}}=0.08, \mathrm{p}<0.05 ; \beta_{\mathrm{CB}}=0.06, \mathrm{p}>0.05\right.$; Dif. $\left.\chi^{2}=1.49, \mathrm{p}<0.01\right)$. Thus, the hypothesis H11e is also supported. However, none of the other effects of the dimensions of CSR image differed between the savings banks and commercial banks samples (Dif. $\chi^{2}<1.04, p>0.1$ ). Based on these findings, the hypotheses H11b to H11d are not supported. Some additional differences were observed in the effects of C-C identification on customer satisfaction $\left(\beta_{\mathrm{SB}}=0.56, \mathrm{p}<0.05 ; \beta_{\mathrm{CB}}=0.63, \mathrm{p}<0.05\right.$; Dif. $\left.\chi^{2}=5.29, \mathrm{p}<0.01\right)$ and repurchase behavior $\left(\beta_{\mathrm{SB}}=0.05, \mathrm{p}>0.05 ; \beta_{\mathrm{CB}}=0.17, \mathrm{p}<0.05 ;\right.$ Dif. $\left.\chi^{2}=76.47, \mathrm{p}<0.01\right)$, as well as in the effect of customer satisfaction on repurchase behavior $\left(\beta_{\mathrm{SB}}=0.80, \mathrm{p}<0.05 ; \beta_{\mathrm{CB}}=0.82, \mathrm{p}>0.05\right.$; Dif. $\left.\chi^{2}=26.42, \mathrm{p}<0.01\right)$. In the three cases, the effects of $\mathrm{C}-\mathrm{C}$ identification and satisfaction were stronger among commercial banks customers.

\section{Insert Table 4 about here}

\section{DISCUSSION}

The results presented in this paper confirm the validity of the cognitive-affective-conative sequence to understand the effects of of CSR image on customer affection and behaviour. Specifically, CSR image influences the affective responses of customers, such as their identification with the company and satisfaction. Subsequently, these affective responses determine customer recommendation and repurchase behaviours. 
These ideas are mostly valid for customer-related CSR images, which significantly and positively affect customer identification with the company and satisfaction among savings banks customers and commercial banks customers. The findings of the present paper have demonstrated that no significant differences exist between savings banks customers and commercial banks customers in terms of the effects of the customer dimension of CSR image on identification and satisfaction. These findings are justified based on the results reported by previous scholars (Pérez and Rodríguez del Bosque, 2014). These scholars have demonstrated that both savings banks customers and commercial banks customers are customer-centric and that there are no significant differences in the importance that they give to these CSR initiatives. Thus, the authors of the present paper consider that these previous findings justify the absence of significant differences in the influence of the customer dimension of the CSR image on identification and satisfaction. Somehow, we can say that CSR expectations are more important than the CSR tradition of banking institutions when determining customer affective and conative responses in the banking industry. The authors also believe that this result derives from the current context of the banking industry worldwide. When a recession occurs and customers perceive uncertainty in the strength and ethics of companies, it is logical that customers resort to CSR concerns such as transparency, honesty or the security of products to reassure their buying decisions. In the latest downturn context, the erosion of the banking industry's image has prompted a feeling of fear among customers about the security of their savings, which has favoured the adoption of switching behaviours (Matute et al., 2011). Thus, in order to keep customers loyal, companies need to recover customer trust in their robustness by triggering satisfaction feelings based on CSR initiatives oriented to enhance the procedures to comply with customers' complaints, 
corporate information about products and services or the procedures oriented to understand customer needs and demands.

On the contrary, society and employee issues have different impacts on affective responses depending on whether customers contract their banking services to a savings bank or a commercial bank. While these issues are relevant to generate identification and satisfaction among savings banks customers, they are irrelevant for commercial banks customers. These results confirm the relevance of the type of company when understanding customer responses in the banking industry. The CSR tradition of savings banks in Spain (Pérez and Rodríguez del Bosque, 2012) seems to determine the impact of a larger number of CSR images on customer responses in this subsector. In terms of identification and satisfaction, the findings of this paper demonstrate that savings banks customers respond to the CSR initiatives oriented to society and employees better than commercial banks customers. In this regard, savings banks have been traditionally linked to CSR through their foundations and their voluntary financing of social projects and their management boards include many stakeholders who are frequently the beneficiaries of the CSR initiatives of savings banks (Pérez and Rodríguez del Bosque, 2012). This tradition has taken savings banks customers to be more concerned about community and employees than commercial banks customers (Pérez and Rodríguez del Bosque, 2014) and, when savings banks meet their customers' expectations, it results in greater identification and satisfaction.

Nonetheless, the findings also demonstrate that the dimension of CSR image that reflects customer perceptions of employee issues is the least influential on customer identification and satisfaction with savings banks and commercial banks. For example, it does not influence customer identification in either a positive or a negative way in none of the customer 
samples. It does not influence the satisfaction of commercial banks customers, and the influence on the satisfaction of savings banks customers is slightly inferior to the effects of CSR community and CSR customers. When comparing these results with the expectations of customers, which are reported by Pérez and Rodríguez del Bosque (2014) in a recent paper, the findings demonstrate that this result is not derived from low customer expectations. On the contrary, customer expectations concerning employee issues are even greater than community or shareholders issues. The authors of this paper believe that the low impact of CSR employees on identification and satisfaction is justified by companies' initiatives and/or communication not meeting customer expectations. These results have significant implications for banking institutions that will be discussed in the following section.

The findings have also revealed some significant differences between savings banks customers and commercial banks customers concerning the role of identification and satisfaction in the generation of loyalty behaviours, especially the repurchase of banking services. The influence of these two affective variables on customer repurchase is higher among commercial banks customers than savings banks customers. This means that commercial banks customers are more prone to keep loyal to their banking institution when it gets to stimulate their affective responses. The justification of the authors for this result is based on the turbulence experienced by the Spanish savings banks in the year that this research was implemented. In 2010, a national law forced savings banks to modify their management systems in order to refinance their capitals and solve cash-flow problems (Pérez and Rodríguez del Bosque, 2014). Some savings banks received financial assistance from the national government to consolidate their financial accounts and others disappeared due to insurmountable economic problems (e.g., Caja Castilla-La Mancha). Regardless of the level of satisfaction with savings banks, these problems led to a climate of uncertainty among 
customers, also motivating switching behaviours towards commercial banks (Bravo et al., 2012). In this context, when commercial banks customers perceive that their providers are expanding their customer portfolio because other consumers assume that they are more reliable, it is logical that identification and satisfaction feelings derive in stronger loyalty behaviours.

Nonetheless, the findings have not revealed significant differences in the effects of identification and satisfaction on customers' recommendation behaviour. This result might be justified by the fact that recommendation behaviour is less biding for customers than repurchase behaviour. While recommending a company does not require that customers spend money or sign long-term commitments with their banking companies, repurchasing banking services is a high-involvement behaviour which requires an additional effort on the part of customers. Thus, recommending a company is easier for customers than actually buying its services and spending money on them and this fact might justify that savings banks customers and commercial banks customers behave similarly in this regard.

\section{CONCLUSIONS, IMPLICATIONS, LIMITATIONS AND FUTURE LINES OF RESEARCH}

From a theoretical perspective, this paper has tried to bridge some gaps in the literature on the effects of CSR image on customer loyalty. In this regard, the paper contributes to academic literature in three different ways.

Firstly, the results of the study provide support for the premise that CSR image affects customer loyalty based on the theoretical contributions of the hierarchy of effects model. The 
paper contributes to a better understanding of how CSR image can positively impact customer recommendation and repurchase behaviour, especially through the triggering of customer identification with the company and satisfaction. As a novelty of the paper, the authors have provided theoretical support for the inclusion of satisfaction in CSR-based loyalty models and the findings of the paper have suggested how scholars should include this construct in new models that study CSR image and customer loyalty.

Secondly, the paper also gives additional explanation to the mixed results that have been reported by previous scholars when studying CSR image from a reflective approach. Understanding CSR image as a formative construct, the authors have broken it into three different dimensions, which provides further information to understand how it is possible that CSR image has positive effects for companies in some studies (García de los Salmones et al., 2005) and negative effects according to other researchers (Carrigan and Attalla, 2001). Thus, the formative approach presents itself as a better alternative than the reflective conceptualization for the study of CSR image in theoretical and empirical research.

Thirdly, the authors have also explored the role of the type of company on the affective and conative responses of customers to their banking institutions. Although previous scholars have neglected the study of both types of companies separately, the authors demonstrate that customer responses to CSR image differ between savings banks and commercial banks significantly. The authors demonstrate that customer-centric CSR images are especially relevant to generate identification and satisfaction among savings banks customers and commercial banks customers. On the contrary, customer perceptions about the CSR oriented to society and employees only affect customer responses in the savings banks subsector. These findings are justified by the long CSR tradition of savings banks as well as by the 
confidence crisis that has significantly affected savings banks and commercial banks in the last decade.

The managerial implications derived from the study are also interesting. First, the findings of the paper suggest that banking institutions should search for better CSR strategies in the internal sphere of employees as well as better tools to communicate the CSR initiatives that they orient to these stakeholders. Scholars have demonstrated that employees are important for customers (Pérez and Rodríguez del Bosque, 2014) but the results of this paper negate a positive effect of this dimension of CSR image on customer identification, satisfaction and, consequently, loyalty behaviours. A better management of this dimension is needed.

Secondly, the results have also suggested that banking institutions should especially care for the implementation of good CSR initiatives oriented to customers. This dimension of CSR image is the most relevant for the generation of customer identification, satisfaction and loyalty.

The third implication concerns savings banks. The results of the paper have demonstrated that these institutions are especially vulnerable to switching behaviours due to the latest economic crisis. Thus, the main goal of savings banks in the current context of the banking industry should be to restore their credibility and customer confidence in its financial strength. In doing so, they will be in a better position to benefit from customer affective and conative responses, just as commercial banks are doing nowadays.

Nonetheless, this study has some limitations that have to be addressed in future research on the topic. Basically, the authors have cantered their attention on the banking industry, 
where product and services complexity and perceived risk can lead to the overestimation of some CSR issues, such as customer-related concerns (Pérez et al., 2013). Also, the context of the Spanish banking industry during and after the global recession might be different to the context of other countries and industries, because the consequences of the crisis have especially affected the savings banks and commercial banks operating in the country. Even when the conceptual model proposed in this paper is based on previous multisectorial literature, the authors consider that it would still be interesting to test the model in other types of industries and countries where the characteristics of the Spanish banking industry would not bias the influence of the dimensions of CSR image on customer behaviour. In doing so, future scholars would give additional external generalizability to the findings presented in this paper.

\section{REFERENCES}

Aupperle, K.E.; Carroll, A.B. and Hatfield, J.D. (1985), “An Empirical Examination of the Relationship Between Corporate Social Responsibility and Profitability”, Academy of Management Journal, Vol. 28 No. 2, pp. 446-463.

Bergami, M. and Bagozzi, R.P. (2000), "Self-categorization, affective commitment and group self-esteem as distinct aspects of social identity in the organization", British Journal of Social Psychology Vol. 39, pp. 555-577.

Bravo, R.; Montaner, T. and Pina, J.M. (2012), "Corporate brand image of financial institutions: A consumer approach”, Journal of Product and Brand Management, Vol. 21 No. 4, pp. 232-245. 
Brown, T.J. and Dacin, P.A. (1997), "The company and the product: Corporate associations and consumer product responses", Journal of Marketing, Vol. 61 No. 1, pp. 6884.

Burke, L.; MacKenzie, S.B. and Podsakoff, P.M. (2003), “A critical review of construct indicators and measurement model misspecification in marketing and consumer research", Journal of Consumer Research Vol. 30 No. 2, pp. 199-218.

Carrigan, M. and Attalla, A. (2001), "The myth of the ethical consumer - Do ethics matter in purchase behaviour?", The Journal of Consumer Marketing, Vol. 18 No. 7, pp. 560-577.

García de los Salmones, M.M.; Herrero, Á. and Rodríguez del Bosque, I. (2005), "Influence of corporate social responsibility on loyalty and valuation of services", Journal of Business Ethics Vol. 61 No. 4, pp. 369-385.

García de los Salmones, M.M.; Pérez, A. and Rodríguez del Bosque, I. (2009), “The social role of financial companies as a determinant of consumer behaviour", International Journal of Bank Marketing Vol. 27 No. 6, pp. 467-485.

He, H. and Li, Y. (2011), "CSR and service brand: The mediating effect of brand identification and moderating effect of service quality", Journal of Business Ethics, Vol. 100, pp. 673-688.

Illueca, M.; Pastor, J.M. and Tortosa, E. (2009), "The effects of geographic expansion on the productivity of Spanish savings banks", Journal of Productivity Analysis, Vol. 32, pp. $119-143$

Maignan, I. and Ferrell, O.C. (2001), "Corporate citizenship as a marketing instrument. Concepts, evidence and research directions", European Journal of Marketing, Vol. 35 No. 3/4, pp. 457. 
Marín, L.; Ruiz, S. and Rubio, A. (2009), "The role of identity salience in the effects of corporate social responsibility on consumer behaviour", Journal of Business Ethics, Vol. 84, pp. $65-78$.

Marquina, P. and Vasquez, A.Z. (2013), "Consumer social responses to CSR initiatives versus corporate abilities", Journal of Consumer Marketing, Vol. 30 No. 2, pp. 100-111.

Matute, J.; Bravo, R. and Pina, J.M. (2011), "The influence of corporate social responsibility and price fairness on customer behaviour: Evidence from the financial sector", Corporate Social Responsibility and Environmental Management, Vol. 18, pp. 317-331.

Oliver, R.L. (1997), Satisfaction: A Behavioral Perspective on the Consumer, McGrawHill, New York, NY.

Pérez, A. and Rodríguez del Bosque, I. (2012), "The role of CSR in the corporate identity of banking service providers", Journal of Business Ethics, Vol. 108 No. 2, pp. 145-166.

Pérez, A. and Rodríguez del Bosque, I. (2013), "Measuring CSR image: Three studies to develop and validate a reliable measurement scale", Journal of Business Ethics, published online. Doi: 10.1007/s10551-013-1857-1.

Pérez, A. and Rodríguez del Bosque, I. (2014), "Customer CSR expectations in the banking industry”, International Journal of Bank Marketing, Vol. 32 No. 3, pp. 223-244.

Pérez, A.; García de los Salmones, M.M. and Rodríguez del Bosque, I. (2013), “The effect of corporate associations on consumer behaviour", European Journal of Marketing, Vol. 47 No. 1/2, pp. 218-238.

Salas, V. and Saurina, J. (2002), "Credit risk in two institutional regimes: Spanish commercial and savings banks”, Journal of Financial Services Research, Vol. 22 No. 3, pp. 203-224. 
Sen, S.; Bhattacharya, C.B. and Korschun, D. (2006), "The role of corporate social responsibility in strengthening multiple stakeholder relationships: A field experiment”, Journal of the Academy of Marketing Science, Vol. 34 No. 2, pp. 158-166.

Singh, J.; García de los Salmones, M.M. and Rodríguez del Bosque, I. (2008), "Understanding corporate social responsibility and product perceptions in consumer markets: A cross-cultural evaluation”, Journal of Business Ethics, Vol. 80, pp. 597-611. 
Table 1. Measurement scales

\begin{tabular}{|c|c|}
\hline Factors & Items \\
\hline CSR society & $\begin{array}{l}\text { SOC1) Helps solving social problems; } \underline{\mathrm{SOC} 2)} \text { Uses part of its budget for donations and } \\
\text { social projects to advance the situation of the most unprivileged groups of the society; } \\
\text { SOC3) Contributes money to cultural and social events (e.g., music, sports); } \underline{\mathrm{SOC} 4)} \\
\text { Plays a role in the society beyond the economic benefits generation; } \underline{\mathrm{SOC} 5 \text { ) Is concerned }} \\
\text { with improving the general well-being of society; SOC6) Is concerned with respecting } \\
\text { and protecting the natural environment }\end{array}$ \\
\hline CSR customers & $\begin{array}{l}\text { CUS1) Establishes procedures to comply with customers' complaints; CUS2) Treats its } \\
\text { customers honestly; CUS3) Has employees who offer complete information about } \\
\text { corporate products/services to customers; CUS4) Uses customers' satisfaction as an } \\
\text { indicator to improve the product/service marketing; CUS5) Make an effort to know } \\
\text { customers' needs }\end{array}$ \\
\hline CSR employees & $\begin{array}{l}\text { EMP1) Pays fair salaries to its employees; EMP2) Offers safety at work to its } \\
\text { employees; EMP3) Treats its employees fairly (without discrimination or abuses); } \\
\text { EMP4) Offers training and career opportunities to its employees; EMP5) Offers a } \\
\text { pleasant work environment (e.g., flexible hours, conciliation) }\end{array}$ \\
\hline C-C identification & $\begin{array}{l}\text { IDE1) I strongly identify with my banking company; IDE2) My banking company fits } \\
\text { my personality; IDE3) I feel good being a customer of my banking company; IDE4) I } \\
\text { like saying that I am a customer of my banking company; IDE5) I feel closely linked to } \\
\text { my banking company; IDE6) I have a strong feeling of membership to my banking } \\
\text { company }\end{array}$ \\
\hline Satisfaction & $\begin{array}{l}\text { SAT1) My decision to choose my banking company was the right one; } \underline{\text { SAT2) I feel }} \\
\text { happy about my decision to choose my banking company; } \underline{\text { SAT3) My banking company }} \\
\text { is exactly the banking service provider I need; } \underline{\text { SAT4) Roughly speaking, I am satisfied }} \\
\text { with my banking company }\end{array}$ \\
\hline $\begin{array}{l}\text { Recommendation } \\
\text { behaviour }\end{array}$ & $\begin{array}{l}\text { REC1) When other consumers ask me for advice, I always recommend my banking } \\
\text { company; REC2) I am positive about my banking company when other consumers ask } \\
\text { me about it }\end{array}$ \\
\hline $\begin{array}{l}\text { Repurchase } \\
\text { behaviour }\end{array}$ & $\begin{array}{l}\text { REP1) I always contact my banking company when I need a new banking service; } \\
\text { REP2) My banking company is always my first choice when I need to contract a new } \\
\text { banking service }\end{array}$ \\
\hline
\end{tabular}


Table 2. Internal consistency and convergent validity for the savings banks and commercial banks samples

\begin{tabular}{|c|c|c|c|c|c|c|c|}
\hline Latent factors & Items & $\begin{array}{r}\lambda \\
(\mathrm{SB})^{1}\end{array}$ & $\begin{array}{r}\lambda \\
(\mathbf{C B})\end{array}$ & $\begin{array}{r}R^{2} \\
(\mathrm{SB})\end{array}$ & $\begin{array}{r}\mathbf{R}^{2} \\
(\mathbf{C B})\end{array}$ & Cronbach's $\alpha$ & AVE \\
\hline \multirow{6}{*}{ CSR society } & SOC1 & 0.73 & 0.71 & 0.53 & 0.51 & \multirow{6}{*}{$\begin{array}{l}0.89(\mathrm{SB}) \\
0.88(\mathrm{CB})\end{array}$} & \multirow{6}{*}{$\begin{array}{l}0.56(\mathrm{SB}) \\
0.56(\mathrm{CB})\end{array}$} \\
\hline & SOC2 & 0.73 & 0.70 & 0.54 & 0.49 & & \\
\hline & SOC3 & 0.75 & 0.70 & 0.56 & 0.50 & & \\
\hline & SOC4 & 0.79 & 0.84 & 0.62 & 0.71 & & \\
\hline & SOC5 & 0.80 & 0.82 & 0.64 & 0.67 & & \\
\hline & SOC6 & 0.70 & 0.70 & 0.49 & 0.48 & & \\
\hline \multirow{5}{*}{ CSR customers } & CUS1 & 0.74 & 0.70 & 0.55 & 0.49 & \multirow{5}{*}{$\begin{array}{l}0.85(\mathrm{SB}) \\
0.84(\mathrm{CB})\end{array}$} & \multirow{5}{*}{$\begin{array}{c}0.53(\mathrm{SB}) \\
0.51(\mathrm{CB})\end{array}$} \\
\hline & CUS2 & 0.79 & 0.75 & 0.62 & 0.57 & & \\
\hline & CUS3 & 0.71 & 0.72 & 0.51 & 0.51 & & \\
\hline & CUS4 & 0.66 & 0.73 & 0.43 & 0.53 & & \\
\hline & CUS5 & 0.74 & 0.66 & 0.55 & 0.44 & & \\
\hline \multirow{5}{*}{ CSR employees } & EMP1 & 0.75 & 0.74 & 0.56 & 0.54 & \multirow{5}{*}{$\begin{array}{c}0.87(\mathrm{SB}) \\
0.87(\mathrm{CB})\end{array}$} & \multirow{5}{*}{$\begin{array}{c}0.61(\mathrm{SB}) \\
0.57(\mathrm{CB})\end{array}$} \\
\hline & EMP2 & 0.82 & 0.81 & 0.66 & 0.66 & & \\
\hline & EMP3 & 0.82 & 0.82 & 0.66 & 0.67 & & \\
\hline & EMP4 & 0.80 & 0.76 & 0.64 & 0.57 & & \\
\hline & EMP5 & 0.71 & 0.63 & 0.50 & 0.40 & & \\
\hline \multirow{6}{*}{ C-C identification } & IDE1 & 0.82 & 0.83 & 0.68 & 0.68 & \multirow{6}{*}{$\begin{array}{l}0.93(\mathrm{SB}) \\
0.93(\mathrm{CB})\end{array}$} & \multirow{6}{*}{$\begin{array}{c}0.70(\mathrm{SB}) \\
0.70(\mathrm{CB})\end{array}$} \\
\hline & IDE2 & 0.86 & 0.85 & 0.74 & 0.72 & & \\
\hline & IDE3 & 0.85 & 0.84 & 0.72 & 0.70 & & \\
\hline & IDE4 & 0.86 & 0.87 & 0.73 & 0.75 & & \\
\hline & IDE5 & 0.86 & 0.85 & 0.74 & 0.72 & & \\
\hline & IDE6 & 0.78 & 0.79 & 0.61 & 0.63 & & \\
\hline \multirow{4}{*}{ Satisfaction } & SAT1 & 0.85 & 0.80 & 0.73 & 0.64 & \multirow{4}{*}{$\begin{array}{l}0.92(\mathrm{SB}) \\
0.88(\mathrm{CB})\end{array}$} & \multirow{4}{*}{$\begin{array}{c}0.74(\mathrm{SB}) \\
0.66(\mathrm{CB})\end{array}$} \\
\hline & SAT2 & 0.80 & 0.77 & 0.65 & 0.59 & & \\
\hline & SAT3 & 0.89 & 0.85 & 0.79 & 0.71 & & \\
\hline & SAT4 & 0.89 & 0.82 & 0.79 & 0.68 & & \\
\hline \multirow{2}{*}{ Recommendation behavior } & REC1 & 0.93 & 0.90 & 0.87 & 0.80 & $0.91(\mathrm{SB})$ & $0.84(\mathrm{SB})$ \\
\hline & REC2 & 0.90 & 0.94 & 0.81 & 0.88 & $0.92(\mathrm{CB})$ & $0.85(\mathrm{CB})$ \\
\hline \multirow{2}{*}{ Repurchase behavior } & REP1 & 0.85 & 0.89 & 0.72 & 0.80 & $0.88(\mathrm{SB})$ & $0.78(\mathrm{SB})$ \\
\hline & REP2 & 0.92 & 0.91 & 0.85 & 0.83 & $0.90(\mathrm{CB})$ & $0.81(\mathrm{CB})$ \\
\hline
\end{tabular}

${ }^{1} \mathrm{SB}=$ Savings Banks; CB $=$ Commercial Banks

Goodness of fit indexes:

Savings Banks: S-B $\chi 2(380)=652.59(\mathrm{p}<0.01)$; NFI=0.94; NNFI=0.97; CFI=0.97; IFI=0.97; RMSEA=0.03

Commercial Banks: S-B $\chi 2(380)=562.21(\mathrm{p}<0.01)$; NFI=0.93; NNFI=0.97; CFI=0.98; IFI=0.98; RMSEA=0.03 
Table 3. Discriminant validity for the savings banks and commercial banks samples

\begin{tabular}{lrrrrrrr}
\hline \hline & $\mathbf{( 1 )}$ & $\mathbf{( 2 )}$ & $\mathbf{( 3 )}$ & $\mathbf{( 4 )}$ & $\mathbf{( 5 )}$ & $\mathbf{( 6 )}$ & $\mathbf{( 7 )}$ \\
\hline \hline $\mathbf{1})$ & - & $0.59-0.75$ & $0.54-0.70$ & $0.37-0.53$ & $0.34-0.50$ & $0.37-0.53$ & $0.20-0.40$ \\
$(\mathbf{2})$ & $0.40-0.60$ & - & $0.45-0.65$ & $0.43-0.59$ & $0.50-0.66$ & $0.44-0.60$ & $0.34-0.54$ \\
$\mathbf{( 3 )}$ & $0.54-0.70$ & $0.52-0.72$ & - & $0.25-0.41$ & $0.29-0.45$ & $0.27-0.43$ & $0.23-0.43$ \\
$\mathbf{( 4 )}$ & $0.23-0.43$ & $0.37-0.57$ & $0.27-0.47$ & - & $0.65-0.77$ & $0.65-0.77$ & $0.45-0.61$ \\
$\mathbf{( 5 )}$ & $0.26-0.46$ & $0.44-0.64$ & $0.30-0.50$ & $0.68-0.80$ & - & $0.74-0.82$ & $0.71-0.83$ \\
$\mathbf{( 6 )}$ & $0.27-0.47$ & $0.41-0.61$ & $0.25-0.45$ & $0.67-0.79$ & $0.72-0.84$ & - & $0.69-0.81$ \\
$\mathbf{( 7 )}$ & $0.13-0.33$ & $0.31-0.51$ & $0.20-0.40$ & $0.35-0.55$ & $0.61-0.77$ & $0.59-0.75$ & - \\
\hline \hline
\end{tabular}

Recommendation behavior; (7) Repurchase behavior

The figures over the diagonal indicate the intervals for the correlation between pairs of latent factors in the savings banks sample. The figures below the diagonal represent the intervals for the correlation between pairs of latent factors in the commercial banks sample 
Table 4. Differences in the causal relationships between savings banks and commercial banks customers (multigroup comparison)

\begin{tabular}{|c|c|c|c|}
\hline \multirow{2}{*}{ Causal relationship } & \multicolumn{2}{|c|}{ Standardized loadings } & \multirow{2}{*}{ Dif. $\chi^{2}(1)$} \\
\hline & SB & CB & \\
\hline CSR society $\rightarrow$ C-C identification & 0.24 & n.s. & $2.51 *$ \\
\hline CSR customers $\rightarrow$ C-C identification & 0.38 & 0.31 & 0.31 \\
\hline CSR customers $\rightarrow$ Satisfaction & 0.28 & 0.25 & 0.18 \\
\hline CSR employees $\rightarrow$ C-C identification & n.s & n.s. & 0.99 \\
\hline CSR employees $\rightarrow$ Satisfaction & 0.08 & n.s. & $1.49 *$ \\
\hline C-C identification $\rightarrow$ Satisfaction & 0.56 & 0.63 & $5.29 *$ \\
\hline C-C identification $\rightarrow$ Recommendation behavior & 0.28 & 0.27 & 1.03 \\
\hline C-C identification $\rightarrow$ Repurchase behavior & n.s. & 0.17 & $76.47 *$ \\
\hline Satisfaction $\rightarrow$ Recommendation behavior & 0.59 & 0.59 & 0.33 \\
\hline Satisfaction $\rightarrow$ Repurchase behavior & 0.80 & 0.82 & $26.42 *$ \\
\hline
\end{tabular}


Figure 1. Conceptual model

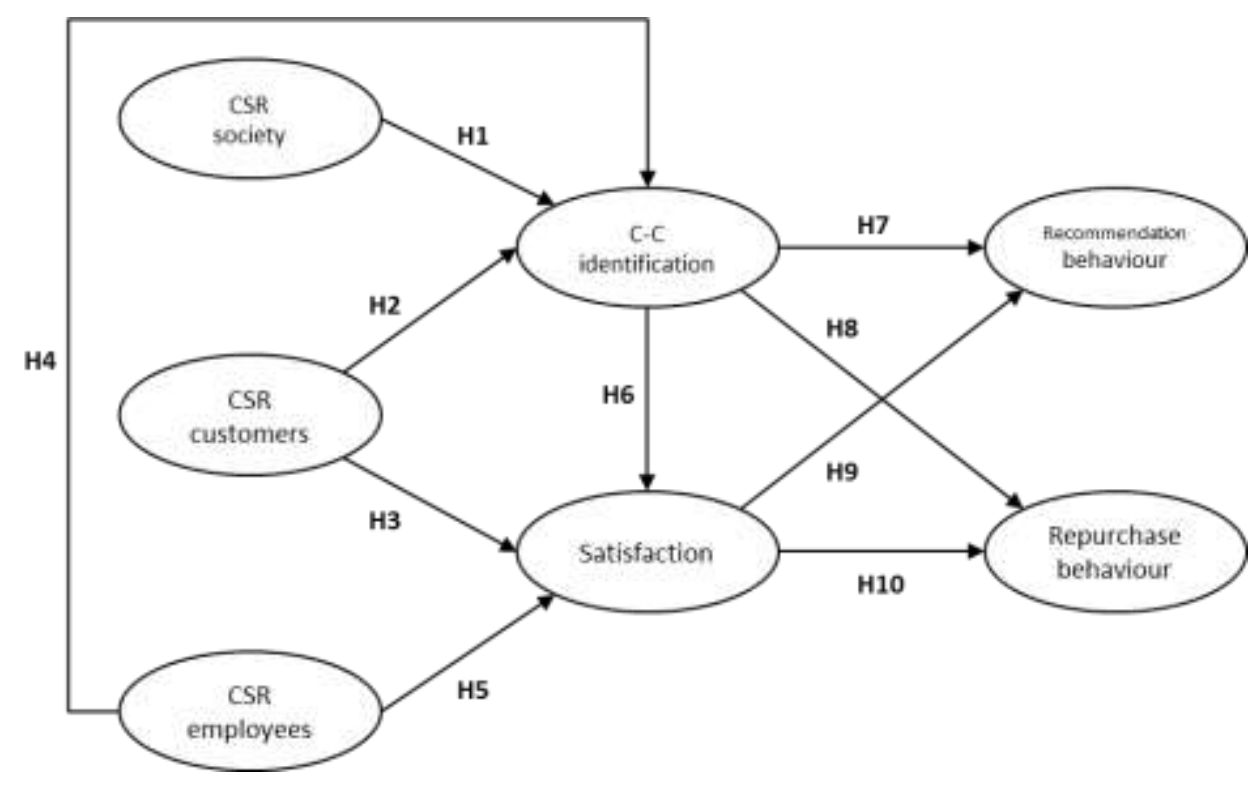


Figure 2. Structural model estimation in the savings banks sample

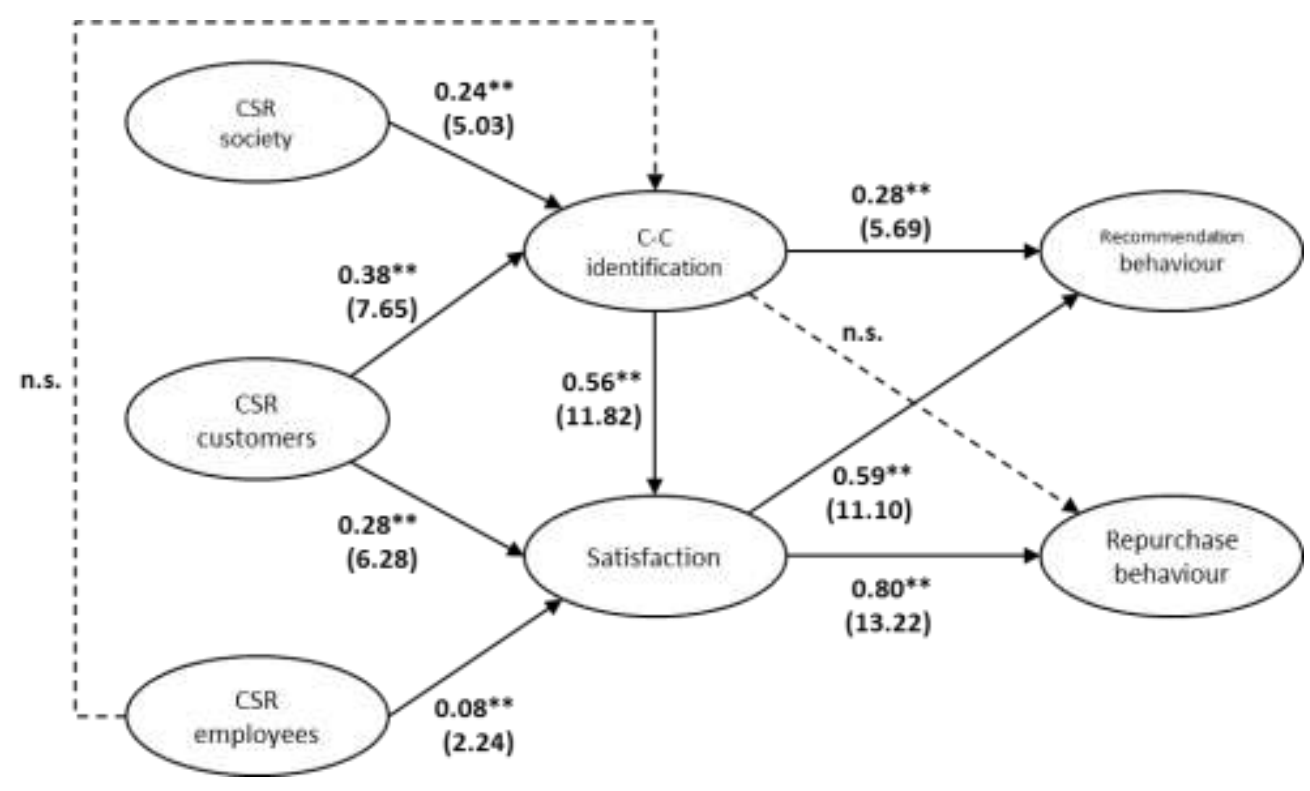

** Standardized path coefficients are significant at $\mathrm{p}<0.05$

Goodness of fit indexes: S-B $\chi 2(391)=1090.69(\mathrm{p}<0.01) ; \quad \mathrm{NFI}=0.89 ; \quad \mathrm{NNFI}=0.92 ; \quad \mathrm{CFI}=0.93 ; \quad \mathrm{IFI}=0.93$; RMSEA $=0.05$ 
Figure 3. Structural model estimation in the commercial banks sample

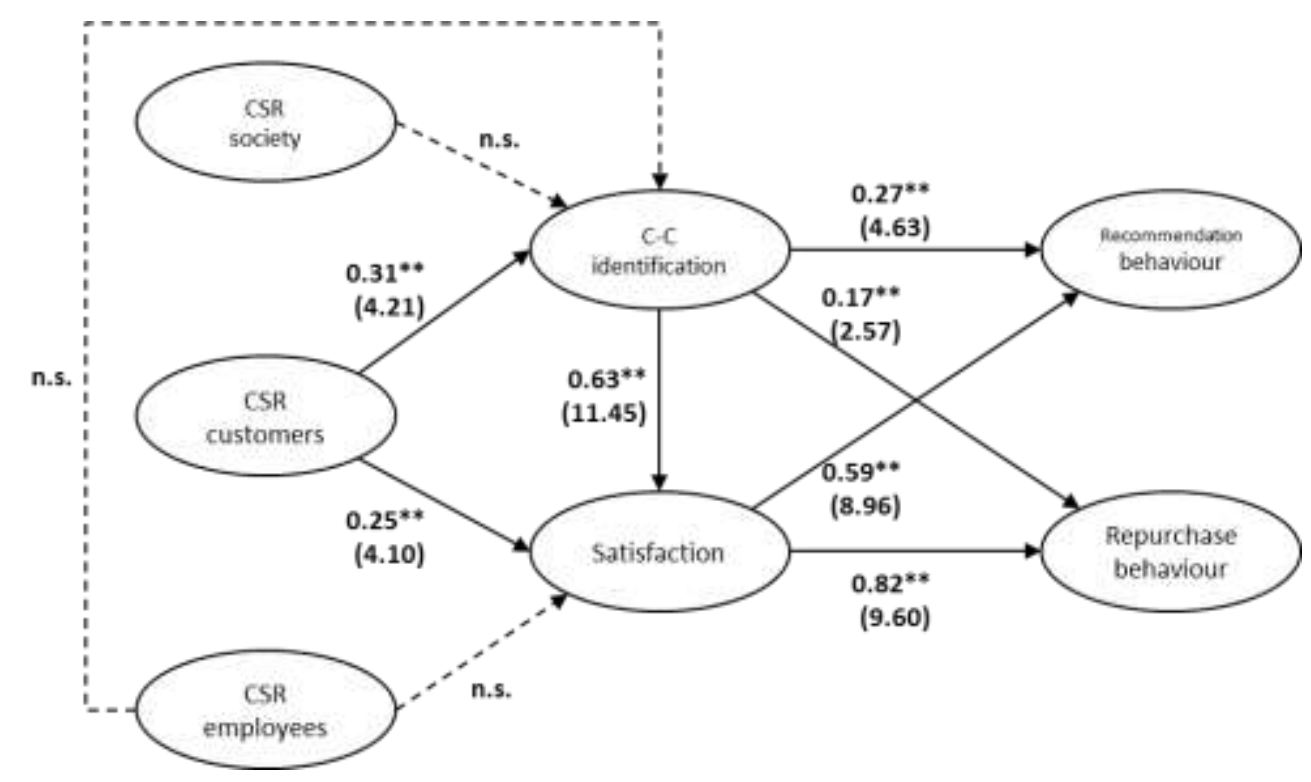

** Standardized path coefficients are significant at $\mathrm{p}<0.05$

Goodness of fit indexes: $\quad \mathrm{S}-\mathrm{B} \chi 2(391)=851.79(\mathrm{p}<0.01) ; \quad \mathrm{NFI}=0.89 ; \quad \mathrm{NNFI}=0.93 ; \quad \mathrm{CFI}=0.94 ; \quad \mathrm{IFI}=0.94$; RMSEA $=0.05$ 